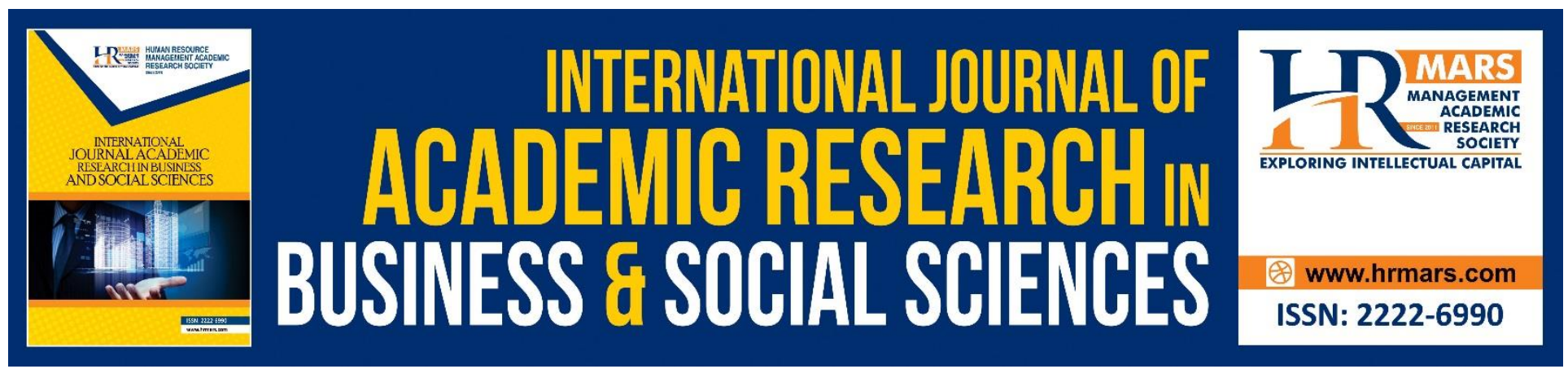

\title{
The Effect of Negative Mood on Industrial Production: First Evidence from Turkish TV Series Finales
}

İbrahim BOZKURT, RIfat KARAKUŞ

To Link this Article: http://dx.doi.org/10.6007/IJARBSS/v8-i9/4550 DOI: $10.6007 /$ IJARBSS/v8-i9/4550

Received: 11 August 2018, Revised: 25 August 2018, Accepted: 21 Sept 2018

Published Online: 10 October 2018

In-Text Citation: (BOZKURT \& KARAKUŞ, 2018)

To Cite this Article: BOZKURT, İ., \& KARAKUŞ, R. (2018). The Effect of Negative Mood on Industrial Production: First Evidence from Turkish TV Series Finales. International Journal of Academic Research in Business and Social Sciences, 8(9), 69-89.

\section{Copyright: (C) 2018 The Author(s)}

Published by Human Resource Management Academic Research Society (www.hrmars.com)

This article is published under the Creative Commons Attribution (CC BY 4.0) license. Anyone may reproduce, distribute, translate and create derivative works of this article (for both commercial and non-commercial purposes), subject to full attribution to the original publication and authors. The full terms of this license may be seen at: http://creativecommons.org/licences/by/4.0/legalcode

Vol. 8, No. 9, September 2018, Pg. 69 - 89 http://hrmars.com/index.php/pages/detail/IJARBSS JOURNAL HOMEPAGE

Full Terms \& Conditions of access and use can be found at http://hrmars.com/index.php/pages/detail/publication-ethics 


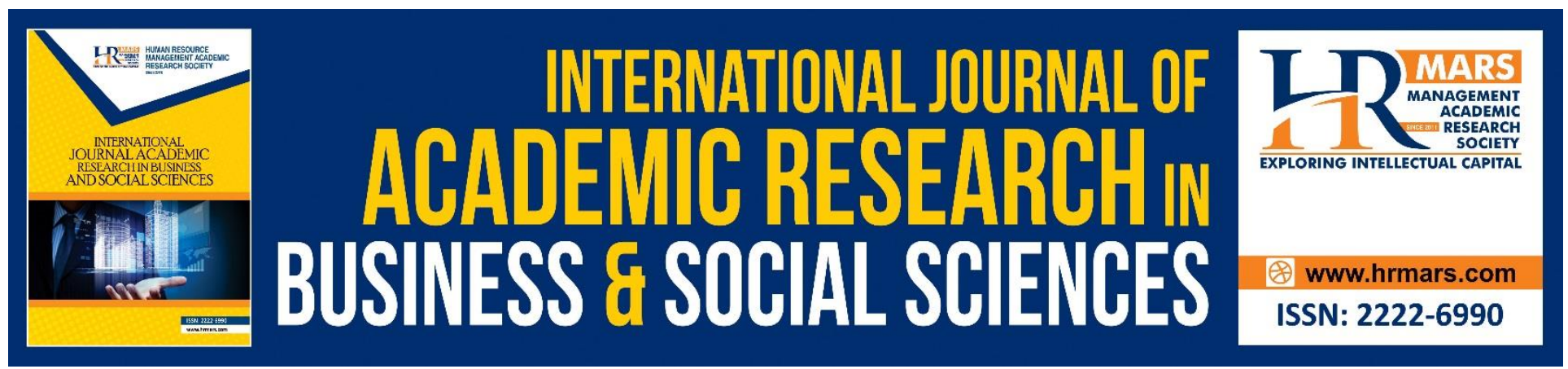

\title{
The Effect of Negative Mood on Industrial Production: First Evidence from Turkish TV Series Finales
}

\author{
İbrahim BOZKURT (Assoc. Prof.) $)^{1^{*}}$, Rıfat KARAKUŞ (Asst. Prof.) ${ }^{2}$ \\ 1, 2 Department of Banking and Finance, Cankiri Karatekin University, Turkey. \\ *Corresponding Author: Email: ibozkurt@karatekin.edu.tr
}

\begin{abstract}
This paper analyses the impact of parasocial breakup (PB) on the industrial production performance in Turkey. We employ 139 Turkish TV series finales, broadcasted between 2005 and 2015, as a negative mood proxy. We use the regression analysis with Newey-West standard errors to obtain a more efficient parameter and provide alternative mood proxy dummies and other macroeconomic variables to examine the robustness of the effect of PB on industrial production. The analysis presents robust evidence that the negative mood decreases the workers' productivity and performance and so industrial production. We also find that the effect of PB on production depends on the types of TV series and the channels they are broadcasted on.
\end{abstract}

Keywords Industrial Production Performance, Productivity, Workers' Mood, Parasocial Breakup

\section{Introduction}

Industrial production (IP) is a leading indicator of the overall performance of the economic activity ${ }^{1}$ in a country. Forecasting the future level of IP and knowing of its current level can significantly impact business activity and profits, inflation and interest rates and therefore stock market performance (because investors' investment decisions can be affected macroeconomic variables). Thus, in order to forecast the economic condition of a country, detecting the determining factors of IP has become momentous for the academicians, investors and policy makers, while one area of agreement among economists is that forecasting economic activity is hard (Faust, Gilchrist, Wright and Zakrajšsek, 2013). Some studies on factors influencing the IP reveal that economic variables such as oil prices, import and export values, supplies of money and inflation rates have a significant effect on the change in the level of IP (Lee and Ni, 2002; Al Mamun and Nath, 2005; Barısık and Yayar, 2012). Variations in workers' mood are also one of the important factors explaining the change in IP because

\footnotetext{
${ }^{1}$ The production, distribution and consumption of goods and services at all levels within a society represent the economic activity.
} 
INTERNATIONAL JOURNAL OF ACADEMIC RESEARCH IN BUSINESS AND SOCIAL SCIENCES Vol. 8, No. 9, Sept. 2018, E-ISSN: 2222-6990 @ 2018 HRMARS

mood $^{2}$ can increase or lose the performance and productivity of the workers (Berument ve Yucel, 2005).

This study analyses how the workers' mood affects the Turkish industrial production performance (in other words, workers productivity) and adopts TV series finales (i.e. parasocial breakup) as the representative of the workers' negative mood.

This paper, which interprets parasocial breakup as a proxy for the workers' negative mood and analyses the relationship between the IP and negative mood of workers in Turkey, aims four major contributions to the literature. First, for the first time in the literature, we employ parasocial breakup (here, TV series finales) as a novel mood proxy to investigate the response of the industrial production performance to exogenous variations in workers' mood. Second, this study examines the episode counts of the TV series that reached their finales to analyse its effect on IP for Turkey. Third, this study also analyses the effect of parasocial breakup on IP considering the types of series and TV channels. Fourth, this is the first paper (of which we are aware) to examine the effect of parasocial breakup on IP in Turkey as an emerging market (also, in the world). Investigating the relationship between TV series finales and IP by using data from Turkey has various advantages (RTÜK, 2013; NTV, 2013): (i) the most preferred programs by the audience are the TV serials in Turkey, so they play an important role in both the society and the media. (ii) Most of the viewers in Turkey identify themselves with TV personae. (iii) Turkey is the second major TV series exporting country after the USA. (iv)Viewers from all of the geographic regions of Turkey allow us to observe the impact of TV series in the whole country. In addition, there is a very strong psychological and emotional relationship between viewers and the TV persona/personae in Turkey and viewers feel a deep sadness in the breakup of the TV persona ${ }^{3}$.

The following sections of the study are designed to depict some studies in the literature related to mood-productivity and parasocial breakup-mood, the explanations related to the data and methodology of the study, the empirical results and the conclusion of the study.

\section{Parasocial Breakup, Mood and Productivity}

Productivity is closely related to both positive and negative mood (George and Brief, 1996) because mood influences a wide range of determinants of a worker's productivity and job performance or work achievement. To put it more explicitly, mood can raise or decrease the productivity and job performance of workers in any industry by stimulating negatively or positively their (i)self-esteem (Baumeister, Campbell, Krueger, \& Vohs, 2003); (ii) perception level and reasoning skill and behavior (Totterdell, Briner, Parkinson, \& Reynolds, 1996); (iii) creativity (Forgas, 2000; Amabile, Barsade, Mueller, \& Staw, 2005; Madjar, Oldham, \& Pratt, 2002; Binnewies and Wörnlein, 2011; George \& Zhou, 2002); (iv) original thinking (Lyubomirsky, King, \& Diener, 2005); (v) motivation (George \& Brief, 1996; Okoye \& Ezejiofor, 2013 ); (vi) heart rate and blood pressure (llies, Dimotakis \& Watson, 2010); (vii) effort (Seo, Bartunek, \& Barrett, 2010); (viii) job satisfaction (Fuller et al., 2003; Connolly \& Viswesvaran, 2000; Judge \& Ilies, 2004; Mignonac \& Herrbach, 2004; Weiss, Nicholas, \& Daus, 1999); (ix) optimism and willingness to take risks (Ashkanasy \& Humphrey, 2011); (x) aggressive and

\footnotetext{
2 Psychologists as their discipline requires, differentiate concepts of "affect", "mood" and "emotion" from one another but in behavioral economics they are used instead of one another (Lepori, 2010). In this paper, they will be used as in behavioural economics.

${ }^{3}$ For instance, because of the supposition of death of a character, police officer Mesut, being shot in $398^{\text {th }}$ episode of a TV series called Arka Sokaklar, in the first day following the broadcasted episode, fifty one thousand people organized over Facebook announced that they would make a funeral rite in a cemetery called Karacaahmet (https://www.facebook.com/events/227488377612252/).
} 
INTERNATIONAL JOURNAL OF ACADEMIC RESEARCH IN BUSINESS AND SOCIAL SCIENCES Vol. 8, No. 9, Sept. 2018, E-ISSN: 2222-6990 @ 2018 HRMARS

sabotage behaviors (Ashkanasy \& Humphrey, 2011); (xi) helping behavior towards their coworkers or supervisors (George, 1991; Fisher, 2002; Eisenberger et al., 2001); (xii) cooperative behaviors (Carnevale \& Isen, 1986); (xiii) self-efficacies (Tsai, Chen, \& Liu, 2007); (xiv) absenteeism, job burnout and turnover (George, 1989; Credé et al., 2005; Miles et al., 2002; Thoresen et al., 2003; Iverson et al., 1998; George, 1989; Gil et al., 2004); (xv) commitments to their organizations (Herrbach, 2006; Judge et al., 1999; Mignonac \& Herrbach, 2004; Thoresen et al., 2003); (xvi) problem solving skills (Estrada, Isen, \& Young, 1994; Vosburg, 1998) and (xvii) task performances (Miner \& Glomb, 2010; Carnevale \& Isen, 1986).

It is commonly held that the workers in positive mood enhance their work achievement (Staw, Sutton \& Pelled, 1994), but negative mood lowers their performance (Monk, 1990). At this point, if some people want to verify this view of positive (negative) mood promotes (prevents) higher productivity, he/she at first wants for a direct measure of mood. To the best of our knowledge, there is not a direct measure of mood yet. However, factors causing an alteration in the individuals' mood has been employed as proxies for the workers' mood (or morale) in existing empirical studies on the effect of mood on productivity (or job performance). These factors, which are used as mood proxies, can be categorised into three primary subgroups: (a) events on the job; (b) physical working environment and (c) non-job events (exogenous factors). Experiences on the job ${ }^{4}$ (such as job performance, social interaction with coworkers and supervisors, work overload, hours worked and supervisor evaluating) and working environment conditions (such as lighting, interior plants, interior color, noise level and music) impact employee's mood (or morale) and so their productivities and performances (see, Lesiuk, 2005; Padmasiri \& Dhammika, 2014; Lohr, Pearson-Mims, \& Goodwin, 1996; Tennant, 2001; Magnini, \& Parker, 2009; Miner, Glomb, \& Hulin, 2005; Kwallek, Lewis, \& Robbins, 1988; Van Bommel, Van Den Beld, \& Van Ooyen, 2002; Akbari, Dehghan, Azmoon, \& Forouharmajd, 2013; Badayai, 2012; Bono \& Ilies, 2006; Cropanzano \& Wright, 1999). Although there is extensive literature on the effect of work-related mood on productivity, there are a limited number of empirical studies on exogenous mood effects and so little is known the role of exogenous variations in workers' mood on their productivity or performance. In a study, Berument and Yucel (2005) express that results of football matches modify individuals' mood and they use football match results as a mood proxy variable. Their findings show that the number of games won by a football team namely Fenerbahce (i.e. positive mood) has a positive effect on the IP (i.e. workers' productivity). Sleep loss is also an exogenous proxy for negative mood because it has a strong effect on mood (Pilcher \& Huffcutt, 1996). Most of researchers typically suggest that low sleep quantity or quality (i.e. negative mood) is associated with low job satisfaction, poor motivation and poor task performance (Blagrove and Akehurst, 2001; Baranski, Cian, Esquievie, Pigeau, \& Raphel, 1998; Kessler et al., 2011; Pilcher \& Huffcutt, 1996). Lee, Gino and Staats (2014), however, reveal that negative mood increases individual productivity. They pointed out the negative effect of the worse weather (e.g. rain, temperature and visibility) on the human psychology and used it as a proxy for negative mood. In the latest study, weather conditions are again used as a mood proxy (Chen, Hsu, Podolski, \& Veeraraghavan, 2016). They document that there is a strong relationship between sunshineinduced mood and investors' productivity (here, economic value and quality of new patents created by investors).

\footnotetext{
${ }^{4}$ There is a bidirectional relationship between some job-related factors (such as Job performance and supervisor evaluating) and mood. For example, workers with a positive mood increase their performances and their better performance produce positive mood (Coté, 1999)
} 
INTERNATIONAL JOURNAL OF ACADEMIC RESEARCH IN BUSINESS AND SOCIAL SCIENCES Vol. 8, No. 9, Sept. 2018, E-ISSN: 2222-6990 @ 2018 HRMARS

In this paper, for the first time in literature, we interpret parasocial breakup (i.e. TV series finales) as a proxy for the workers' negative $\operatorname{mood}^{5}$. Parasocial breakup describes a condition where the viewers' identification of themselves with certain TV personae ends with the TV series finale (Cohen, 2003). Parasocial breakup causes problems similar to the death of a close friend or break-ups between lovers (Cohen, 2004). These problems show themselves as psychological conditions such as depression, loneliness, anxiety, sleeplessness and stress (Field et al., 2009; Rhoades et al., 2011; Slotter, Gaedner \& Finkel, 2010; McCarthy, Lambert \& Brack, 1997). As a result, in times when the TV series reach their finale, it is prevalently supposed that the mood of the society is negative. In fact, when the long-episode TV series end, the negative mood dominates more over the society (Eyal and Cohen, 2006). This view can be briefly stated as follows: The negative effect of a parasocial breakup on the mood of the society stems from the power of parasocial relationship. Cohen (2003), Cohen (2004) and Eyal and Cohen (2006) reveal that the sad mood evoked by parasocial breakup is more intense when the parasocial relationship is stronger. The longer a viewer watches a TV persona, the stronger the attachment and the parasocial relationship that he/she builds becomes (Rubin and McHugh, 1987); hence, the power of parasocial relationships, which affects the psyche of the society, grows stronger in long-running TV serials and the impact deepens by the tragic or happy endings of their popular characters. For this reason, we use the episode numbers of the TV series that reached their finales to clarify the effect of parasocial breakup (i.e. negative exogenous change in workers' mood) on IP.

In line with commonly held views, the main claim of our paper is that when the long-running TV series end, the exogenous variation in workers' mood is negative and so they become more unproductive by losing their performance (or productivity or concentration) and then the level of IP decreases.

\section{Data and Methodology}

We evaluate the productivity of workers in Turkey by using the Turkish industrial production index (IPI). Productivity is clearly presented with " $g_{t}^{y}$ " monthly rate of growth in IPI, which is computed in Eq.1 as the logarithmic change of IPI (Berument and Yucel, 2005).

$$
g_{t}=\ln \left(I P I_{t}\right)-\ln \left(I P I_{t-1}\right)
$$

Here, monthly data of IPI $(2010=100)^{6}$ are collected for 403 commodities from 918 large-scale firms and are adjusted for the seasonal and calendar factors to control the effect of the unequal number of working days and holidays and observances and seasonal variations on IPI (i.e. productivity). IPI is a standard measure of both IP and economic activity for Turkey because the coverage of the monthly index is about $73 \%$ of gross value of industrial production. In spite of the fact that GDP is a broader measure of economic activity, most of the studies (see, Lee and Ni, 2002; Al Mamun and Nath, 2005; Berument and Yucel, 2005; Juntilla, 2007; Corradi, Distaso and Mele, 2013; Fornari and Mele, 2013; Espinoza, Fornari and Lombardi, 2012) have focused on IP as a proxy variable of the level of economic activity rather than GDP7. We also focus on monthly data of IPI for three reasons (Moody, Levin and Rehfuss, 1993). First, there is more data available for IPI than for

\footnotetext{
${ }^{5}$ In fact, in behavioral economics literature, Lepori (2015) had employed TV series finales (i.e. parasocial breakup) as a mood proxy to measure exogenous variations in investors' mood.

${ }^{6}$ The monthly data on IPI for Turkey is collected from TUIK (Turkish Statistical Institute) website from January 2006 to April 2015 (see, http://www.tuik.gov.tr/PreTablo.do?alt id=1024). We collected the index data in 10.04.2016.

${ }^{7}$ Moreover, IP is the crucial component of GDP of a country and also is a leading indicator of GDP.
} 
INTERNATIONAL JOURNAL OF ACADEMIC RESEARCH IN BUSINESS AND SOCIAL SCIENCES Vol. 8, No. 9, Sept. 2018, E-ISSN: 2222-6990 @ 2018 HRMARS

GDP $^{8}$. Second, the IPI is more timely than GDP and is therefore watched more closely by related persons for making decisions. Third, the IPI is more interesting and challenging from a time series forecasting standpoint than GDP.

Another data set used in the study consists of information related to 139 Turkish TV series ${ }^{9}$ ended between January, 1, 2005 and April, 30, 2015 (e.g., types of series, dates of finales, episode numbers and the TV channels that broadcast these series). The information related to series that reached finales was obtained from several sources ${ }^{10}$ by cross-checking to ensure the reliability of the data. The finale dates of TV series represent the dates when the negative mood dominates on the workers and this study assumes that negative mood will affect the workers' performance on the month in the dates of the finale ${ }^{11}$. Table 1 presents the statistical summary related to TV series and IPI. In table 1, we also report some descriptive statistics of other control variables which are used for controlling macroeconomic factors and alternative mood proxy to ensure the robustness of the analysis results.

Table 1: Summary Statistics of Variables

\begin{tabular}{|c|c|c|c|c|c|c|c|}
\hline \multicolumn{2}{|r|}{ Period: January, 2006 - April, 2015(Monthly) } & Symbol & Mean & St. Dev. & Median & Max. & Min. \\
\hline \multirow[t]{3}{*}{ A - } & Total Episode Numbers (Raw Data) & - & 81.35 & 144.39 & 28.00 & 867.00 & 0.00 \\
\hline & IPI (Raw Data) & - & 104.64 & 11.22079 & 102.0000 & 123.500 & 79.40000 \\
\hline & Log change of IPI & $g$ & 0.003 & 0.02140 & 0.00253 & 0.06598 & -0.05274 \\
\hline \multirow[t]{13}{*}{ B- } & Log change of the gold prices (\$/Ons) & Gold & 0.0075 & 0.05572 & 0.00925 & 0.12731 & -0.16645 \\
\hline & Log change of the Brent oil prices (\$ / Barrel) & Oil & -0.0007 & 0.10303 & 0.00860 & 0.26420 & -0.44383 \\
\hline & $\begin{array}{r}\text { Log change in the numbers of newly-established } \\
\text { companies }\end{array}$ & Open & 0.0017 & 0.11825 & 0.00000 & 0.37318 & -0.31353 \\
\hline & Log change in the numbers of closing companies & Close & -0.0059 & 0.28399 & 0.00000 & 1.01724 & -0.96500 \\
\hline & $\begin{array}{r}\text { Log ch. of the weighted aver. interest on commercial } \\
\text { loans }\end{array}$ & Comm. & -0.0033 & 0.05737 & -0.00692 & 0.15778 & -0.14370 \\
\hline & Log change of the weighted average interest on deposits & Deposit & -0.0050 & 0.10069 & -0.00432 & 0.29242 & -0.27404 \\
\hline & Log change of export values of Turkey (\$) & Export & 0.0049 & 0.11 & 0.01353 & 0.23117 & -0.34478 \\
\hline & Log change of import values of Turkey (\$) & Import & 0.0042 & 0.10621 & 0.01042 & 0.24299 & -0.36062 \\
\hline & Log change of CPI & Cpi & 0.0066 & 0.00796 & 0.00561 & 0.03219 & -0.01441 \\
\hline & Log change of M2 money supply (\$) & Money & 0.0195 & 0.05115 & 0.01608 & 0.23973 & -0.10276 \\
\hline & Log change of public expenditure (\$) & Public & 0.0172 & 0.19735 & 0.00021 & 0.56333 & -0.54052 \\
\hline & Log change in number of workers & Worker & 0.0027 & 0.01626 & -0.00118 & 0.03906 & -0.02958 \\
\hline & Total number of strikers to total number of workers ratio & Strike & 0.00007 & 0.00020 & 0.00002 & 0.00129 & 0.00000 \\
\hline \multirow[t]{3}{*}{ C- } & Average monthly temperature in Istanbul $\left({ }^{\circ} \mathrm{C}\right)$ & Temp & 14.3495 & 6.74386 & 14.0433 & 26.8871 & 2.68275 \\
\hline & $\begin{array}{l}\text { Av. monthly rate of cloudiness in Istanbul (Max=10; } \\
\qquad \text { Min=0) }\end{array}$ & Cloud & 4.1702 & 1.16164 & 4.18000 & 7.77272 & 1.53871 \\
\hline & Total rainfall in Istanbul $\left(\mathrm{mm}=\mathrm{kg} / \mathrm{m}^{2}\right)$ & Rain & 70.7666 & 58.5494 & 57.6000 & 254.500 & 0.00000 \\
\hline
\end{tabular}

Notes: (1) All variables are in monthly frequency. Panel A shows the summary statistics of TV series and IPI; Panel B shows the summary statistics concerning the macroeconomic control variables and Panel $\mathrm{C}$ displays some summary statistics

\footnotetext{
${ }^{8} \mathrm{GDP}$ is computed by the Turkish Statistical Institute for Turkey on only a quarterly basis, while IPI is computed and published monthly. ${ }^{9}$ Selection criteria of TV series in this paper are as follows: (i) their finales must have minimum rating $1 \%$ and share $2 \%$. (ii)They must be broadcasted for at least 20 episodes to have enough parasocial relationship with viewers. In Turkey, the seasonal broadcasting of TV series is nearly 35-36 episodes. (iii)Finally, the TV series finales, broadcasted at the time of the Turkish National Team matches, are excluded from the study.

10 All the information (except ratings) related to the TV series was obtained from the web sites http://www.bizimhikayelerimiz.com/forum/forumdisplay.php?108-D\%C4\%BOZ\%C4\%BO-AR\%C5\%9E\%C4\%BOV\%C4\%B0,

http://tr.wikipedia.org/wiki/Kategori:T\%C3\%BCrk televizyon dizileri

and http://www.imdb.com/search/title?countries=tr\&start=1\&title type=tv series, http://www.ddizi1.com/; the ratings were obtained from the web sites http://www.ucankus.com/ratingler, http://www.canlitv.com/rating/ and http://www.tvaktuel.com/tv/tv-rating/ between 01.04.2015-07.06.2015.

${ }^{11}$ But a TV series actually ended in month $t$ is considered for month $t+1$ if the first workday after the finale dates of this TV series belongs to month $t+1$
} 
related with alternative mood proxies. (2) If more than one finale aired on the same month, in line with Berument and Yucel (2005) and Lepori (2015), we compute the total number of episodes by adding up the episode numbers of the relevant finales. We follow the same approach when calculating TV ratings and audience shares to numerically represent the intensity of negative mood in the relevant month. (3) Because of space limitations, summary statistics of raw data for macroeconomic variables are not presented. (4) Log change of macroeconomic control variables is expressed in USD values in order to control the effect of volatile exchange rate on IPI. (5) All meteorological variables data, as alternative

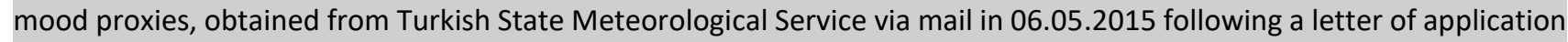
in 15.04.2015. (6) Macroeconomic variables collected from Central Bank of the Republic of Turkey and Turkish Statistical Institute. (7) While gold prices are obtained from Borsa Istanbul stock exchange database, oil prices from US Energy Information Administration. (8) All data are stationary in level. (9) Some information related to TV series that reached their finales is as follows: 1- The TV series with the number of the highest episode is "A woman - A man" (375 episodes). 2- The highest rating of finale is "Aşk-ı Memnu" (rating $=23.41 \%$, Share $=58.55 \%$ ).

Before stating the empirical analyses and to give some idea about the relationship between the negative mood and productivity of workers in Turkey, the performance of IPI and natural logarithm of total episode numbers of finales in the relevant month are given together in Fig. 1.

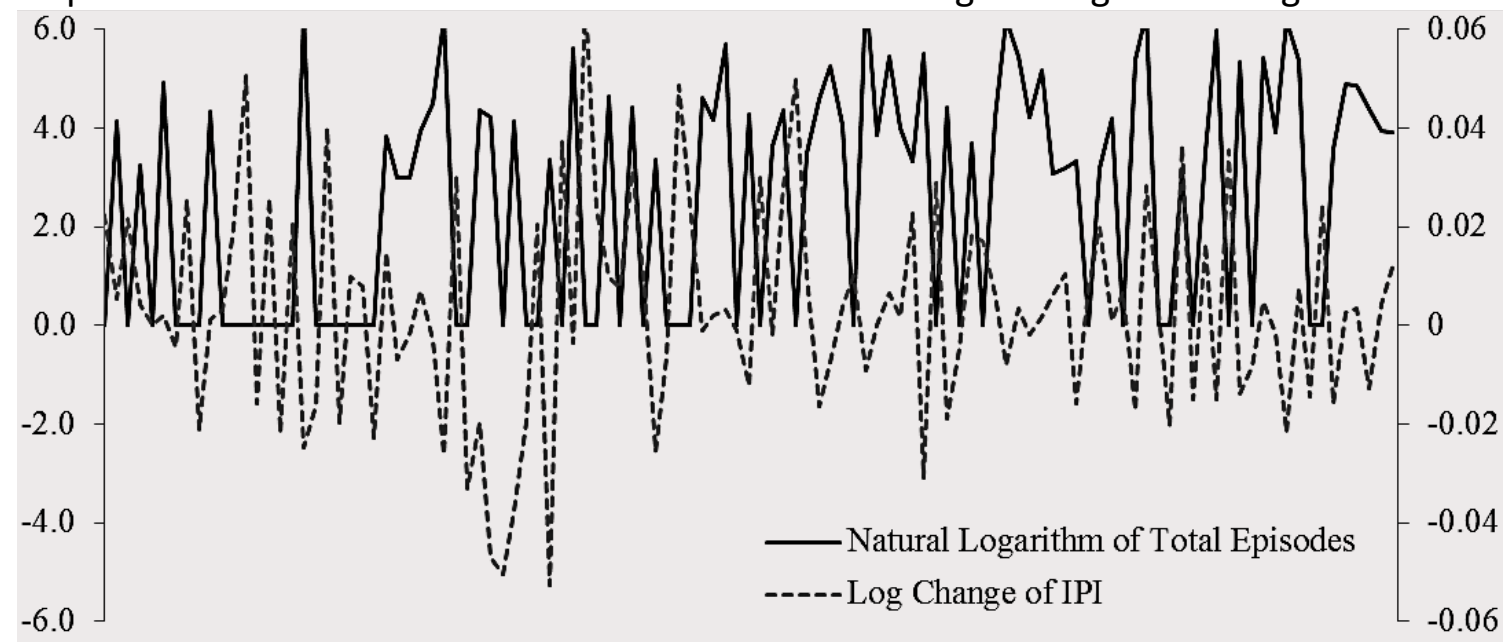

Figure 1: Total Episodes of TV Series that Reached Their Finales and the Performance of IPI

To determine the relationship between national productivity growth and negative mood due to parasocial breakup (TV series finales), ordinary least squares (OLS) regression method is used. OLS regression analyses are performed using Newey-West method ${ }^{12}$.

We estimated the following specifications in Eq. 2.

$$
\begin{aligned}
g_{t}= & \alpha_{0}+\sum_{i=1}^{2} \lambda_{i} g_{t-i}+\sum_{j=1}^{J} \beta_{\mathrm{j}} \mathrm{Z}_{j t}+\gamma_{l} \text { Oil }_{t}+\gamma_{2} \text { Gold }_{t}+\gamma_{3} \text { Open }_{t}+\gamma_{4} \text { Close }_{t} \\
& +\gamma_{5} \text { Comm }_{t}+\gamma_{6} \text { Deposit }_{t}+\gamma_{7} \text { Export }_{t}+\gamma_{8} \text { Import }_{t}+\gamma_{9} \text { Cpi }_{t} \\
& +\gamma_{10} \text { Money }_{t}+\gamma_{11} \text { Public }_{t}+\gamma_{12} \text { Worker }_{t}+\gamma_{13} \text { Strike }_{t} \\
& +\varphi_{1} \text { Cloud }_{\mathrm{t}}+\varphi_{2} \text { Temp }_{t}+\varphi_{3} \text { Rain }_{\mathrm{t}}+\varepsilon_{t}
\end{aligned}
$$

\footnotetext{
12 Newey-West method gives robust standard errors in case there is a possibility that error terms in regression equations may have heteroskedastic and autocorrelation problems and provides coherent coefficient predictions.
} 
In this model (Eq. 2), the dependent variable " $g$ " is thought to follow an autoregressive path, and therefore the study includes it to Eq. 2 as an independent variable until the $2^{\text {nd }}$ lag length ${ }^{13}$. In Eq. 2 , $\mathrm{Z}_{\mathrm{j}}$ is set of the workers' negative mood proxy variables for Turkey (see, Table 3). Other variables in Eq. 2, which we suppose to affect the industrial production performance, are shown in Table 1.

For each month $t, Z_{t}$ in Table 3 specifies a cluster of negative mood proxy variables in Table 2. Table 2 shows a list of negative mood proxies represented by episode numbers of Turkish TV series which are ended.

In Table 2, we denote the natural logarithm of total episode numbers of TV series reached their finales with F. A subscript of " $d$ " refers to drama TV series, "a" and " $c$ " stand for the action and comedy TV series, respectively. The superscript "All” predicates all TV series; “A", "D", "Sh", "St" and "O" are for the TV series broadcasted on ATV, Channel D, Show TV, Star TV and other TV channels, respectively.

We, in analogy to Lepori (2015) and Berument and Yucel (2005), compute the total number of episodes by summing up the episode numbers of the relevant finales for each month to numerically represent the intensity of negative mood in the relevant month. These total episode numbers are shown in Fig. 2.

Table 2: List of Negative Mood Proxies

\begin{tabular}{|c|c|}
\hline$F^{\text {All }}$ & $=$ In (the total number of episodes of TV series reached their finales in month $\mathrm{t}$ ) \\
\hline$F_{d}$ & $=$ In (the total number of episodes of Drama TV series reached their finales in month $\mathrm{t}$ ) \\
\hline$F_{a}$ & $=$ In (the total number of episodes of Action TV series) \\
\hline$F_{c}$ & $=$ In (the total number of episodes of Comedy TV series) \\
\hline$F^{A}$ & $=$ In (the total number of episodes of TV series broadcasted on ATV) \\
\hline$F^{D}$ & $=$ In (the total number of episodes of TV series broadcasted on Channel D) \\
\hline$F^{S h}$ & $=$ In (the total number of episodes of TV series broadcasted on Show TV) \\
\hline$F^{S t}$ & $=$ In (the total number of episodes of TV series broadcasted on Star TV) \\
\hline$F^{O}$ & $=$ In (the total number of episodes of TV series broadcasted on other channels) \\
\hline$F_{d}^{A}$ & $=$ In (the total number of episodes of Drama TV series broadcasted on ATV) \\
\hline$F_{a}^{A}$ & $=$ In (the total number of episodes of Action TV series broadcasted on ATV) \\
\hline$F_{c}^{A}$ & $=$ In (the total number of episodes of Comedy TV series broadcasted on ATV) \\
\hline$F_{d}^{D}$ & $=$ In (the total number of episodes of Drama TV series broadcasted on Channel D) \\
\hline$F_{a}^{D}$ & $=$ In (the total number of episodes of Action TV series broadcasted on Channel D) \\
\hline$F_{c}^{D}$ & $=$ In (the total number of episodes of Comedy TV series broadcasted on Channel D) \\
\hline$F_{d}^{S h}$ & $=$ In (the total number of episodes of Drama TV series broadcasted on Show TV) \\
\hline$F_{a}^{S h}$ & $=$ In (the total number of episodes of Action TV series broadcasted on Show TV) \\
\hline$F_{c}^{S h}$ & $=$ In (the total number of episodes of Comedy TV series broadcasted on Show TV) \\
\hline$F_{d}^{S t}$ & $=$ In (the total number of episodes of Drama TV series broadcasted on Star TV) \\
\hline
\end{tabular}

\footnotetext{
13 The related lag length is determined according to the FPE (Final Predict Error) criterion. If there is an autocorrelation between error terms in a regression model, the reliability of the model decreases. At this point FPE criterion determines the lag length that diminishes the autocorrelation between error terms. The results were found robust, but not shown here due to space limitation.
} 
INTERNATIONAL JOURNAL OF ACADEMIC RESEARCH IN BUSINESS AND SOCIAL SCIENCES Vol. 8, No. 9, Sept. 2018, E-ISSN: 2222-6990 @ 2018 HRMARS

$$
\begin{array}{ll}
F_{a}^{S t} & =\ln \text { (the total number of episodes of Action TV series broadcasted on Star TV) } \\
F_{c}^{S t} & =\ln \text { (the total number of episodes of Comedy TV series broadcasted on Star TV) } \\
F_{d}^{O} & =\ln \text { (the total number of episodes of Drama TV series broadcasted on other TV channels) } \\
F_{a}^{O} & =\ln \text { (the total number of episodes of Action TV series broadcasted on other TV channels) } \\
F_{c}^{O} & =\ln \text { (the total number of episodes of Comedy TV series broadcasted on other TV channels) }
\end{array}
$$

The negative mood proxies in the 8 model specifications considered in this paper are demonstrated in Table 3, where Specification 1 is the most general model. Subsequent specifications are designed to take the TV Channels and types of TV series into account in order to ensure the robustness of the analysis results.

Table 3: Specifications of the Study

\begin{tabular}{ll}
\hline Specification 1 & $\mathrm{Z}=\left[F^{A l l}\right]$ \\
Specification 2 & $\mathrm{Z}=\left[F_{d}, F_{a}, F_{c}\right]$ \\
Specification 3 & $\mathrm{Z}=\left[F^{A}, F^{D}, F^{S h}, F^{S t}, F^{O}\right]$ \\
Specification 4 & $\mathrm{Z}=\left[F_{d}^{A}, F_{a}^{A}, F_{c}^{A}\right]$ \\
Specification 5 & $\mathrm{Z}=\left[F_{d}^{D}, F_{a}^{D}, F_{c}^{D}\right]$ \\
Specification 6 & $\mathrm{Z}=\left[F_{d}^{S h}, F_{a}^{S h}, F_{c}^{S h}\right]$ \\
Specification 7 & $\mathrm{Z}=\left[F_{d}^{S t}, F_{a}^{S t}, F_{c}^{S t}\right]$ \\
Specification 8 & $\mathrm{Z}=\left[F_{d}^{O}, F_{a}^{O}, F_{c}^{O}\right]$ \\
\hline
\end{tabular}
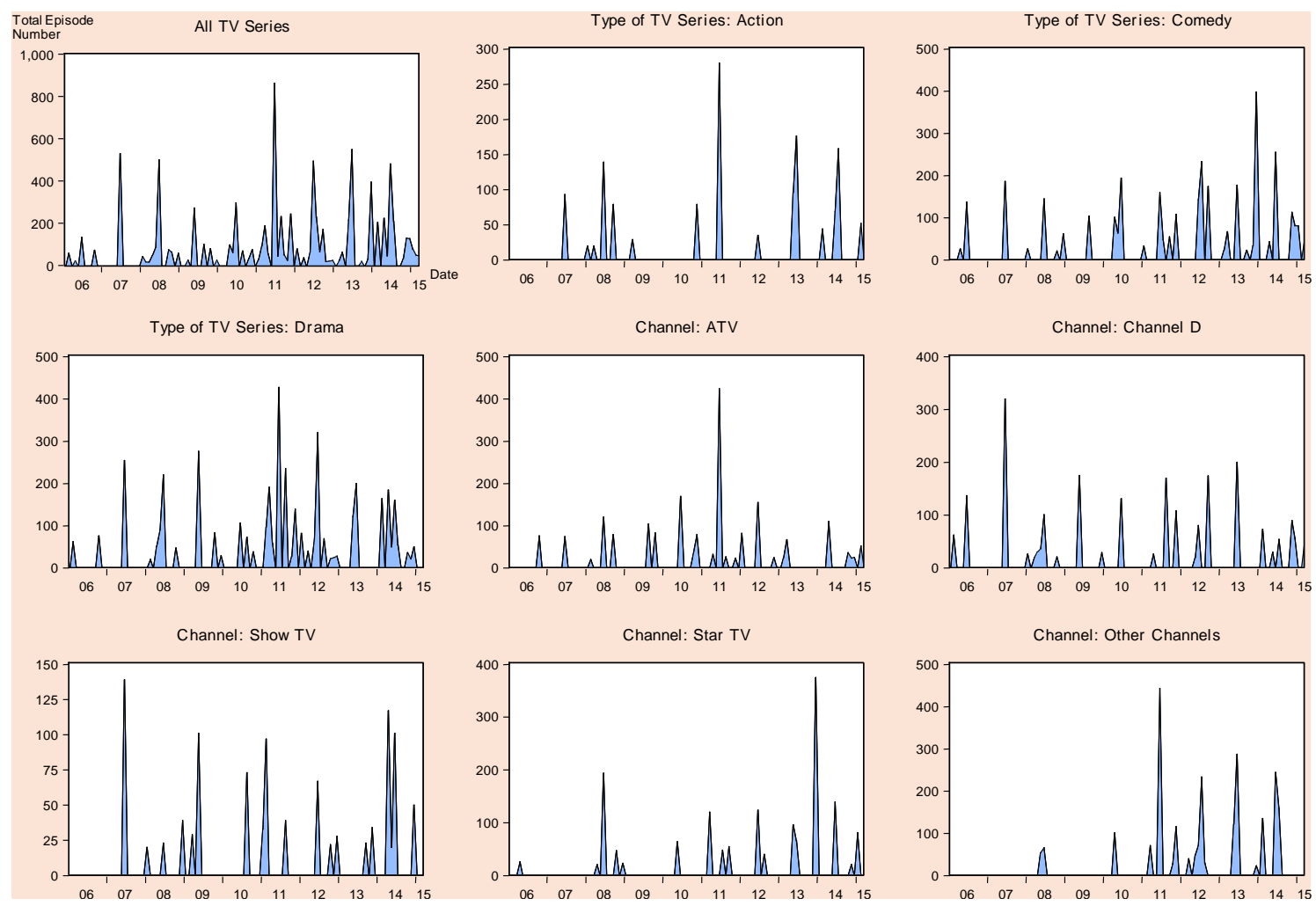

Figure 2: The Total Episode Numbers on TV Channel and Type of TV Series Basis 
INTERNATIONAL JOURNAL OF ACADEMIC RESEARCH IN BUSINESS AND SOCIAL SCIENCES Vol. 8, No. 9, Sept. 2018, E-ISSN: 2222-6990 @ 2018 HRMARS

In Eq. 2, $\beta$ coefficient is tested under the null hypothesis $\left(\mathrm{H}_{0}: \beta_{\mathrm{j}}=0\right)$ and measure the effect of TV series finales (parasocial breakup, in other words, negative mood) on Turkish industrial production performance.

\section{Empirical Results}

The results showing the relationship between TV series finales (workers' negative mood) and Turkish industrial performance are summarised in Table 4 and 5.

Specification 1 of Table 4 shows statistically significant evidence that industrial production in Turkey reacts negatively to TV series finales. $\beta_{1}$ is estimated to be negative and statistically significant at $1 \%$ level (the null hypothesis " $\mathrm{H}_{0}: \beta_{1}=0$ " is rejected). Regression coefficient $\beta_{1}$ suggests that negative changes in the workers' mood, caused at the end of the long-episode TV series (which has a stronger parasocial relationship), decrease the Turkish industrial production in the same month. The magnitude of the corresponding coefficient estimate is -0.00223 . Therefore, parasocial breakups (TV series finales) are transformed into decreased productivity. When everything is stable, it is forecasted that workers will response to the ending of the TV series with $25 \%$ more episodes by decreasing Turkish industrial performance nearly 5 basis points on the same month ${ }^{14}$.A quick glance at these findings shows that the first results are coherent with the main claim of this paper.

Specifications 2 are designed to test if the findings related to specification 1 will stay the same after the ended series are grouped according to types. For the same purpose, specifications 3 also groups the ended series according to TV channels and specifications 4-8 group the TV series according to both TV channels and types. The purpose of this grouping is to establish the robustness of the study results.

When coefficients $\left(\beta_{\mathrm{j}}\right)$ of the specifications 2-8 in Table 4 and 5 are considered, it is seen that the effects on productivity of TV series finales (parasocial breakups) still turn out to be negative and statistically significant. Turkish industrial production responds negatively to the drama TV series finales (except action and comedy) and the finales broadcasted on Show TV and Star TV channels (except ATV, Channel D and other channels), specifically. In addition, the effects on industrial production of both drama and action TV series aired on Show TV and drama TV series aired on both Star TV and Other channels (except ATV and Channel D) are negative and statistically significant.

As for the rest of the variables; whereas the coefficients of COMM, STRIKE and CLOUD are statistically significant and negative, the coefficients of OIL, OPEN, EXPORT and CPI are positive and statistically different from zero for nearly all specifications. For instance, although the raise in the industrial production performance due to a percentage increase in the new firms established in Turkey varies between 4.6 basis points (Spec. 02) and 5.8 basis points (Spec. 06), the decreasing effect in the production performance of a percentage increase in the interest rates for commercial loans ranges from 7 basis points (Spec. 01) to 11 basis points (Spec. 06). As regards "strike" variable, the decline in the industrial production growth rate changes between \%10 (Spec. 01) and \%13(Spec. 04) when there is a percentage point increase in the number of strikers to the total number of workers ratio, all else equal.

\footnotetext{
14 In fact, the intensity of the response changes according to a baseline episode count. In this calculation, the baseline number of the episodes has been supposed to be equal to the average episode count " 81 ". According to this supposition, a $25 \%$ increase in the episode count causes a decrease in the industrial production performance on the same month when related TV series finales, which is $\mathrm{E}\left(g_{T}\right)-\mathrm{E}\left(g_{t}\right)=\left[\beta_{1} \times \ln \left(\right.\right.$ Episode $\left.\left._{\mathrm{T}}\right)\right]-\left[\beta_{1} \times \ln \left(\right.\right.$ Episode $\left.\left._{\mathrm{t}}\right)\right]=[-0.00223 \times \ln (81 * 1.25)]-[-0.00223 \times \ln (81)]=-0.0005$
} 
INTERNATIONAL JOURNAL OF ACADEMIC RESEARCH IN BUSINESS AND SOCIAL SCIENCES Vol. 8, No. 9, Sept. 2018, E-ISSN: 2222-6990 @ 2018 HRMARS

It may seem very interesting that the rate of cloudiness has statistically significant negative effect on industrial performance. People cherish their lives on sunny days more than they do on cloudy days (Schwarz \& Clore, 1983) so the cloudy weather is the representative of negative mood. At this point, our result on CLOUD contributes to the robustness of the positive correlation between workers' mood and production performance.

Finally, when the explanatory variables are considered as a whole, the hypothesis that the coefficients of all explanatory variables are equal to zero cannot be accepted statistically for all specifications (see, F-statistics).

Our findings related to the effect of negative mood due to TV series finales on industrial production can make some readers suspicious because they are fairly interesting and surprising. Presenting robustness of the results can eliminate probable suspicions.

Table 4: Results of Regression Analysis (Eq. 2 and Specification 1 -4)

\begin{tabular}{|c|c|c|c|c|}
\hline Explanatory Variables & Spec. 01 & Spec. 02 & Spec. 03 & Spec. 04 \\
\hline \multirow{2}{*}{$g_{t-1}$} & $-0.13081^{c}$ & $-0.13347^{c}$ & $-0.15179^{b}$ & $-0.13166^{c}$ \\
\hline & {$[0.073786]$} & [0.075888] & [0.07388] & {$[0.074561]$} \\
\hline \multirow{2}{*}{$g_{t-2}$} & $0.14981^{c}$ & 0.12754 & 0.12059 & 0.14101 \\
\hline & [0.089102] & [0.096385] & [0.083713] & [0.094961] \\
\hline \multirow{2}{*}{$\beta_{1} F^{A l l}$} & $-0.00223^{a}$ & & & \\
\hline & {$[0.0006]$} & & & \\
\hline \multirow{2}{*}{$\beta_{1} F_{d}$} & & $-0.00183^{b}$ & & \\
\hline & & [0.000882] & & \\
\hline \multirow{2}{*}{$\beta_{2} F_{a}$} & & -0.00153 & & \\
\hline & & [0.001496] & & \\
\hline \multirow{2}{*}{$\beta_{3} F_{c}$} & & -0.00044 & & \\
\hline & & [0.000857] & & \\
\hline \multirow{2}{*}{$\beta_{1} F^{A}$} & & & 0.00044 & \\
\hline & & & [0.000514] & \\
\hline \multirow{2}{*}{$\beta_{2} F^{D}$} & & & -0.00007 & \\
\hline & & & [0.001047] & \\
\hline \multirow[t]{2}{*}{$\beta_{3} F^{S h}$} & & & $-0.00169^{b}$ & \\
\hline & & & {$[0.000786]$} & \\
\hline \multirow[t]{2}{*}{$\beta_{4} F^{S t}$} & & & $-0.00394^{a}$ & \\
\hline & & & [0.00101] & \\
\hline \multirow[t]{2}{*}{$\beta_{5} F^{O}$} & & & -0.00107 & \\
\hline & & & [0.000932] & \\
\hline \multirow{2}{*}{$\beta_{1} F_{d}^{A}$} & & & & -0.00123 \\
\hline & & & & [0.000981] \\
\hline \multirow[t]{2}{*}{$\beta_{2} F_{a}^{A}$} & & & & 0.00114 \\
\hline & & & & [0.002331] \\
\hline \multirow[t]{2}{*}{$\beta_{3} F_{c}^{A}$} & & & & 0.00069 \\
\hline & & & & {$[0.001238]$} \\
\hline \multirow[t]{2}{*}{ Oil } & $0.03907^{b}$ & $0.04199^{b}$ & $0.04042^{b}$ & $0.04136^{b}$ \\
\hline & [0.016582] & [0.016593] & [0.017467] & {$[0.017374]$} \\
\hline Gold & -0.03960 & -0.04537 & -0.03702 & -0.03709 \\
\hline
\end{tabular}


INTERNATIONAL JOURNAL OF ACADEMIC RESEARCH IN BUSINESS AND SOCIAL SCIENCES Vol. 8, No. 9, Sept. 2018, E-ISSN: 2222-6990 @ 2018 HRMARS

\begin{tabular}{|c|c|c|c|c|}
\hline & {$[0.029394]$} & {$[0.031403]$} & {$[0.028817]$} & {$[0.029287]$} \\
\hline \multirow[t]{2}{*}{ Open } & $0.04761^{a}$ & $0.04673^{a}$ & $0.05550^{a}$ & $0.04999^{a}$ \\
\hline & [0.015054] & [0.014598] & [0.016445] & [0.016412] \\
\hline \multirow[t]{2}{*}{ Close } & -0.00006 & 0.00039 & 0.00074 & 0.00074 \\
\hline & [0.007602] & [0.007908] & [0.006776] & [0.008825] \\
\hline \multirow[t]{2}{*}{ Comm } & $-0.07252^{b}$ & $-0.08374^{b}$ & $-0.09682^{a}$ & $-0.08113^{b}$ \\
\hline & [0.031281] & [0.033781] & [0.034284] & [0.036979] \\
\hline \multirow[t]{2}{*}{ Deposit } & -0.00587 & 0.00108 & -0.00524 & -0.00533 \\
\hline & [0.020292] & [0.019677] & [0.020714] & [0.020091] \\
\hline \multirow[t]{2}{*}{ Export } & 0.03249 & $0.04018^{c}$ & 0.02837 & $0.03968^{c}$ \\
\hline & {$[0.021636]$} & [0.024617] & [0.021554] & [0.022928] \\
\hline \multirow[t]{2}{*}{ Import } & -0.00762 & -0.01927 & -0.01000 & -0.01181 \\
\hline & [0.026128] & [0.029822] & [0.026065] & [0.029218] \\
\hline \multirow[t]{2}{*}{ Cpi } & $0.34737^{c}$ & $0.33311^{c}$ & $0.34115^{c}$ & $0.47855^{a}$ \\
\hline & [0.18203] & [0.203068] & [0.176676] & [0.175356] \\
\hline \multirow[t]{2}{*}{ Money } & -0.01697 & -0.02275 & -0.01832 & -0.03114 \\
\hline & [0.038035] & [0.036017] & [0.040755] & [0.033368] \\
\hline \multirow[t]{2}{*}{ Public } & 0.01352 & 0.01481 & $0.01741^{c}$ & 0.01451 \\
\hline & [0.010233] & [0.010381] & [0.009598] & [0.011718] \\
\hline \multirow[t]{2}{*}{ Worker } & 0.05365 & 0.07707 & 0.03225 & 0.00660 \\
\hline & [0.108608] & [0.111137] & [0.11217] & [0.1135] \\
\hline \multirow[t]{2}{*}{ Strike } & $-13.33715^{b}$ & $-11.33738^{c}$ & $-11.75127^{c}$ & $-10.70518^{c}$ \\
\hline & [6.67286] & [6.740709] & [6.937634] & [6.570212] \\
\hline \multirow[t]{2}{*}{ Cloud } & $-0.00340^{b}$ & $-0.00315^{c}$ & -0.00486 & $-0.00285^{c}$ \\
\hline & [0.001613] & [0.001639] & [0.00174] & [0.001687] \\
\hline \multirow[t]{2}{*}{ Temp } & -0.00020 & -0.00011 & -0.00035 & -0.00016 \\
\hline & [0.000219] & {$[0.000231]$} & [0.000234] & [0.000243] \\
\hline \multirow[t]{2}{*}{ Rain } & -0.00005 & -0.00005 & -0.00006 & -0.00006 \\
\hline & [0.0000355] & [0.0000362] & [0.000033] & [0.000039] \\
\hline \multirow[t]{2}{*}{$C$} & $0.02678^{a}$ & 0.02313 & 0.03456 & 0.01850 \\
\hline & [0.00857] & [0.008932] & [0.009828] & [0.009093] \\
\hline$R^{2}$ & 0.36166 & 0.36475 & 0.40310 & 0.31560 \\
\hline Adj. $R^{2}$ & 0.22539 & 0.21142 & 0.24159 & 0.15041 \\
\hline SSR & 0.03192 & 0.03176 & 0.02985 & 0.03422 \\
\hline F-statistic & $2.65394^{a}$ & $2.37877^{a}$ & $2.49578^{a}$ & $1.91045^{b}$ \\
\hline
\end{tabular}

Note: $\left({ }^{\text {a }}\right),\left(^{(b)}\right.$ and $\left({ }^{(}\right)$have been used to indicate that the coefficient estimations are statistically significant at $1 \%, 5 \%$ and $10 \%$ level, respectively. $\left({ }^{\text {d }}\right)$ The values given in brackets under related coefficient estimations are Newey-West robust standard errors. 
INTERNATIONAL JOURNAL OF ACADEMIC RESEARCH IN BUSINESS AND SOCIAL SCIENCES Vol. 8, No. 9, Sept. 2018, E-ISSN: 2222-6990 ㄷ 2018 HRMARS

Table 5: Results of Regression Analysis (Eq. 2 and Specification 5 -8)

\begin{tabular}{|c|c|c|c|c|}
\hline $\begin{array}{r}\text { Explanatory } \\
\text { Variables }\end{array}$ & Spec. 05 & Spec. 06 & Spec. 07 & Spec. 08 \\
\hline \multirow{2}{*}{$g_{t-1}$} & $-0.12965^{c}$ & $-0.13621^{c}$ & $-0.15483^{b}$ & $-0.12166^{c}$ \\
\hline & [0.074861] & {$[0.076786]$} & [0.075891] & [0.073179] \\
\hline \multirow{2}{*}{$g_{t-2}$} & 0.13002 & 0.11295 & $0.15325^{c}$ & 0.14601 \\
\hline & [0.09193] & [0.079441] & [0.088069] & [0.090723] \\
\hline \multirow{2}{*}{$\beta_{1} F_{d}^{D}$} & -0.00115 & & & \\
\hline & [0.001407] & & & \\
\hline \multirow{2}{*}{$\beta_{2} F_{a}^{D}$} & -0.00250 & & & \\
\hline & [0.001777] & & & \\
\hline \multirow{2}{*}{$\beta_{3} F_{c}^{D}$} & -0.00082 & & & \\
\hline & [0.001162] & & & \\
\hline \multirow{2}{*}{$\beta_{1} F_{d}^{S h}$} & & $-0.00315^{b}$ & & \\
\hline & & [0.001268] & & \\
\hline \multirow{2}{*}{$\beta_{2} F_{a}^{S h}$} & & $-0.00765^{a}$ & & \\
\hline & & [0.00253] & & \\
\hline \multirow[t]{2}{*}{$\beta_{3} F_{c}^{S h}$} & & -0.00239 & & \\
\hline & & [0.001628] & & \\
\hline \multirow[t]{2}{*}{$\beta_{1} F_{d}^{S t}$} & & & $-0.00325^{a}$ & \\
\hline & & & [0.00106] & \\
\hline \multirow{2}{*}{$\beta_{2} F_{a}^{S t}$} & & & -0.00260 & \\
\hline & & & [0.002164] & \\
\hline \multirow{2}{*}{$\beta_{3} F_{c}^{S t}$} & & & 0.00018 & \\
\hline & & & [0.001358] & \\
\hline \multirow[t]{2}{*}{$\beta_{1} F_{d}^{O}$} & & & & $-0.00289^{b}$ \\
\hline & & & & [0.001142] \\
\hline \multirow[t]{2}{*}{$\beta_{2} F_{a}^{O}$} & & & & 0.00000 \\
\hline & & & & [0.00177] \\
\hline \multirow{2}{*}{$\beta_{3} F_{c}^{O}$} & & & & 0.00015 \\
\hline & & & & [0.001193] \\
\hline \multirow[t]{2}{*}{ Oil } & $0.04165^{b}$ & $0.04415^{a}$ & $0.03904^{b}$ & $0.03754^{b}$ \\
\hline & [0.016225] & [0.0163] & [0.01719] & [0.017853] \\
\hline \multirow[t]{2}{*}{ Gold } & -0.04070 & -0.02981 & -0.04118 & -0.04128 \\
\hline & [0.027882] & [0.027356] & [0.032025] & [0.029695] \\
\hline \multirow[t]{2}{*}{ Open } & $0.05095^{a}$ & $0.05861^{a}$ & $0.05210^{a}$ & $0.04948^{a}$ \\
\hline & [0.01567] & [0.017159] & [0.015496] & [0.015588] \\
\hline \multirow[t]{2}{*}{ Close } & -0.00137 & -0.00116 & -0.00085 & -0.00140 \\
\hline & [0.007916] & [0.007273] & [0.007801] & [0.008223] \\
\hline \multirow[t]{2}{*}{ Comm } & $-0.07932^{b}$ & $-0.10673^{a}$ & $-0.08374^{b}$ & $-0.07405^{c}$ \\
\hline & [0.038257] & [0.036728] & [0.035588] & [0.037848] \\
\hline \multirow[t]{2}{*}{ Deposit } & -0.00086 & 0.00219 & -0.00200 & -0.00567 \\
\hline & [0.021494] & [0.016934] & [0.021293] & [0.019333] \\
\hline \multirow[t]{2}{*}{ Export } & $0.04037^{c}$ & 0.02872 & 0.03586 & $0.04663^{c}$ \\
\hline & [0.023475] & [0.021009] & [0.023803] & [0.023563] \\
\hline
\end{tabular}


INTERNATIONAL JOURNAL OF ACADEMIC RESEARCH IN BUSINESS AND SOCIAL SCIENCES Vol. 8, No. 9, Sept. 2018, E-ISSN: 2222-6990 @ 2018 HRMARS

\begin{tabular}{|c|c|c|c|c|}
\hline \multirow[t]{2}{*}{ Import } & -0.01481 & -0.00598 & -0.01078 & -0.01549 \\
\hline & [0.030664] & [0.025608] & [0.031675] & [0.030505] \\
\hline \multirow[t]{2}{*}{ Cpi } & $0.38027^{b}$ & $0.36618^{b}$ & $0.40226^{b}$ & $0.37402^{c}$ \\
\hline & [0.174448] & [0.17453] & [0.194762] & [0.191117] \\
\hline \multirow[t]{2}{*}{ Money } & -0.02066 & -0.02322 & -0.01737 & -0.02742 \\
\hline & [0.036906] & [0.036013] & [0.036384] & [0.036423] \\
\hline \multirow[t]{2}{*}{ Public } & 0.01593 & 0.01521 & 0.01538 & 0.01573 \\
\hline & [0.010756] & [0.009498] & [0.009983] & [0.010265] \\
\hline \multirow[t]{2}{*}{ Worker } & 0.04725 & 0.00639 & 0.03356 & 0.05109 \\
\hline & [0.121453] & [0.111851] & [0.115537] & [0.114448] \\
\hline \multirow[t]{2}{*}{ Strike } & -9.14575 & $-11.26814^{c}$ & -9.62001 & -9.26578 \\
\hline & [6.216868] & [6.501031] & [6.158365] & [6.27116] \\
\hline \multirow[t]{2}{*}{ Cloud } & $-0.00300^{c}$ & $-0.00473^{a}$ & -0.00260 & $-0.00351^{b}$ \\
\hline & [0.00164] & [0.001772] & [0.001702] & [0.001718] \\
\hline \multirow[t]{2}{*}{ Temp } & -0.00017 & -0.00034 & -0.00007 & -0.00028 \\
\hline & [0.000242] & {$[0.000226]$} & [0.000247] & [0.000242] \\
\hline \multirow[t]{2}{*}{ Rain } & -0.00006 & -0.00005 & -0.00006 & -0.00006 \\
\hline & [0.0000378] & [0.0000342] & [0.0000381] & [0.0000362] \\
\hline \multirow[t]{2}{*}{$C$} & 0.02060 & 0.03155 & 0.01737 & 0.02440 \\
\hline & [0.008951] & [0.009415] & [0.009683] & [0.009847] \\
\hline$R^{2}$ & 0.32607 & 0.39188 & 0.34539 & 0.33866 \\
\hline Adj. $R^{2}$ & 0.16340 & 0.24510 & 0.18738 & 0.17903 \\
\hline$S S R$ & 0.03370 & 0.03041 & 0.03273 & 0.03307 \\
\hline F-statistic & $2.00449^{b}$ & $2.66975^{a}$ & $2.18584^{a}$ & $2.12151^{a}$ \\
\hline
\end{tabular}

Note: $\left({ }^{\mathrm{a}}\right),\left(^{(\mathbf{b}}\right)$ and $\left({ }^{(}\right)$have been used to indicate that the coefficient estimations are statistically significant at $1 \%, 5 \%$ and $10 \%$ level, respectively. $\left({ }^{\text {d }}\right)$ The values given in brackets under related coefficient estimations are Newey-West robust standard errors.

\section{Robustness Checks}

The relationships stated in Table 4 and 5, between the negative mood and industrial production performance, is also supported by quartile analysis. Fig. 3 shows the quartile limits ${ }^{15}$ calculated based on the natural logarithm of episode numbers of ended TV series.

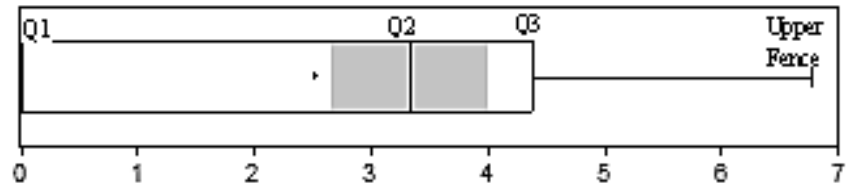

Figure 3: Box-Plot Graphics Related to Natural Logarithm of Episode Number

In the quartile analysis, first, the TV series are divided into four groups, depending on the natural logarithm of episode numbers in Fig. 3. Thereafter, the mean changes in the IPI are calculated for each group (Fig. 4). Fig. 4a shows the average changes in IPI for each of the quartiles. Fig. 4b shows the cumulative average changes in the IPI.

\footnotetext{
${ }^{15}$ Min=0; Qr1 (Lower Quartile) =0; Qr2 (Median) =3.3; Qr3 (Upper Quartile) =4.4; Maximum=6.8 and Upper Fence=10.95.
} 
INTERNATIONAL JOURNAL OF ACADEMIC RESEARCH IN BUSINESS AND SOCIAL SCIENCES Vol. 8, No. 9, Sept. 2018, E-ISSN: 2222-6990 @ 2018 HRMARS

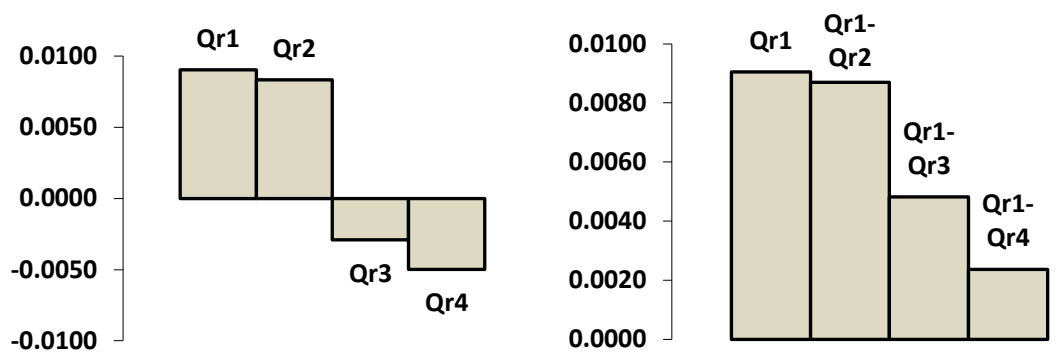

Figure 4: Changes in the IPI on Quartiles Basis

Fig. 4 shows that production performance decreases when the long-episode TV series end (i.e. negative mood dominates over the workers). This relationship between IPI and the negative mood is also statistically significant (Table 6). Table 6 shows that the changes in IPI are different from one another on quartiles basis.

Table 6: Summary Statistics of the Changes in IPI on Quartiles Basis

\begin{tabular}{|c|c|c|c|c|}
\hline PANEL $A^{d}$ & Qr1(low) & Qr2 & Qr3 & Qr4(high) \\
\hline Mean & 0.009044 & 0.008336 & -0.002902 & -0.005488 \\
\hline Maximum & 0.065984 & 0.036245 & 0.031236 & 0.028219 \\
\hline Minimum & -0.050544 & -0.015776 & -0.052741 & -0.030883 \\
\hline Std. Dev. & 0.024502 & 0.016069 & 0.019939 & 0.014787 \\
\hline Jarque-Bera & $0.243335^{f}$ & $0.291058^{f}$ & $3.339427^{f}$ & $0.594087^{f}$ \\
\hline \multicolumn{5}{|c|}{ F-Statistic $=3.998901^{a}$} \\
\hline PANEL B ${ }^{\mathbf{e}}$ & \multicolumn{2}{|c|}{ Qr3 } & \multicolumn{2}{|c|}{ Qr4(high) } \\
\hline Qr1(low) & \multicolumn{2}{|c|}{$t$-Stat. $=2.217^{b}$} & \multicolumn{2}{|c|}{$t-S t a t .=2.9282^{a}$} \\
\hline Qr2 & \multicolumn{2}{|c|}{$t$-Stat $=1.5383$} & \multicolumn{2}{|c|}{ t-Stat. $=2.4131^{\mathrm{b}}$} \\
\hline
\end{tabular}

Note: $\left({ }^{a}\right),\left({ }^{b}\right)$ and $\left({ }^{c}\right)$ have been used to indicate that the coefficient estimations are statistically significant at $1 \%, 5 \%$ and $10 \%$ level, respectively. This means, $\left({ }^{\mathrm{a}}\right),\left(^{\mathrm{b}}\right)$ and $\left({ }^{(}\right)$imply that there is a statistically significant difference between the average changes of IPI belonging to the quartiles. $\left({ }^{d}\right)$ Panel A presents the summary statistics related to production performance for each quartile. Moreover, it includes the statistics which show whether or not the average changes differ on the quartiles basis. ( ${ }^{\mathrm{e}}$ ) Panel B presents the T-statistic values related to differences between the changes in IPI related to groups of TV series which have the most (Qr3 and Qr4) and the least ( $\operatorname{rr} 1$ and Qr2) episodes. (f) The null hypothesis "the related sample presents a normal distribution" cannot be rejected. Thus in this table, only parametric ( $F$ and $t$ tests) test results are given.

On a different approach to analyse the permanence of the relationship between workers' negative mood and Turkish industrial performance over time, the period is divided into two subperiods of 2006-2010 and 2011-2015. Same analysis is then repeated for specification 1 . The results in the second and third column of Table 7 of the two sub-periods are consistent with both each other and with the general results attained in this paper.

In one part of his study, Lepori (2015) uses the ratings and shares of TV series that reached finales as negative mood proxies. It may be intriguing to learn if the relationship found in this study between negative mood and Turkish industrial performance still continues after considering the ratings and shares of the TV series that reached finales. We employ natural logarithm of ratings and shares of TV series reached their finales in month t for specification 1 to satisfy one's curiosity. The results of ratings and shares are shown in the fourth and fifth column of Table 7. 
INTERNATIONAL JOURNAL OF ACADEMIC RESEARCH IN BUSINESS AND SOCIAL SCIENCES Vol. 8, No. 9, Sept. 2018, E-ISSN: 2222-6990 @ 2018 HRMARS

Table 7: Results of Robustness Checks (For Specification 1).

\begin{tabular}{|c|c|c|c|c|}
\hline $\begin{array}{c}\text { (1) } \\
\text { Explanatory Variables }\end{array}$ & $\begin{array}{c}\text { (2) } \\
\text { Robustness } 1 \\
\end{array}$ & $\begin{array}{c}\text { (3) } \\
\text { Robustness } 2 \\
\end{array}$ & $\begin{array}{c}\text { (4) } \\
\text { Robustness } 3 \\
\end{array}$ & $\begin{array}{c}\text { (5) } \\
\text { Robustness } 4 \\
\end{array}$ \\
\hline \multirow{2}{*}{$g_{t-1}$} & $-0.21107^{c}$ & $-0.19901^{c}$ & $-0.14120^{c}$ & $-0.13630^{c}$ \\
\hline & [0.121516] & [0.111113] & [0.073087] & [0.074255] \\
\hline \multirow{2}{*}{$g_{t-2}$} & $0.24280^{a}$ & -0.09537 & 0.11873 & 0.13201 \\
\hline & [0.062207] & [0.094635] & [0.089394] & [0.089524] \\
\hline \multirow{2}{*}{$\beta_{1} F_{2006-2010}^{\text {All }}$} & $-0.00266^{a}$ & & & \\
\hline & [0.000923] & & & \\
\hline \multirow{2}{*}{$\beta_{1} F_{2011-2015}^{\text {All }}$} & & $-0.00204^{a}$ & & \\
\hline & & [0.000714] & & \\
\hline \multirow{2}{*}{$\beta_{1} \mathrm{~F}^{\text {All }}$ Rating } & & & $-0.00518^{a}$ & \\
\hline & & & [0.001354] & \\
\hline \multirow{2}{*}{$\beta_{1} F^{\text {All }}$ Shares } & & & & $-0.00348^{a}$ \\
\hline & & & & [0.000927] \\
\hline \multirow[t]{2}{*}{ Oil } & - & $0.02903^{c}$ & $0.04151^{b}$ & $0.04117^{b}$ \\
\hline & - & [0.016591] & [0.016252] & [0.016522] \\
\hline \multirow[t]{2}{*}{ Gold } & - & $-0.06538^{c}$ & - & - \\
\hline & - & [0.037762] & - & - \\
\hline \multirow[t]{2}{*}{ Open } & - & $0.04711^{a}$ & $0.04980^{a}$ & $0.04967^{a}$ \\
\hline & - & [0.016656] & [0.014532] & [0.014783] \\
\hline \multirow[t]{2}{*}{ Close } & $-0.12196^{a}$ & - & - & - \\
\hline & [0.013002] & - & - & - \\
\hline \multirow[t]{2}{*}{ Comm } & $-0.20527^{a}$ & - & $-0.07245^{b}$ & $-0.07247^{b}$ \\
\hline & [0.06492] & - & [0.031227] & [0.030628] \\
\hline \multirow[t]{2}{*}{ Cpi } & $1.07341^{b}$ & - & - & $0.32219^{c}$ \\
\hline & [0.45117] & - & - & [0.180708] \\
\hline \multirow[t]{2}{*}{ Public } & $0.02716^{c}$ & - & - & - \\
\hline & [0.016164] & - & - & - \\
\hline \multirow[t]{2}{*}{ Strike } & - & - & $-11.17866^{c}$ & $-12.69818^{c}$ \\
\hline & - & - & [6.504345] & [6.545331] \\
\hline \multirow[t]{2}{*}{ Cloud } & $-0.00639^{b}$ & - & - & $-0.00299^{c}$ \\
\hline & [0.002327] & - & - & [0.001618] \\
\hline \multirow[t]{2}{*}{ Rain } & $-0.00011^{c}$ & - & - & - \\
\hline & [0.0000631] & - & - & - \\
\hline \multirow[t]{2}{*}{$C$} & $0.02975^{b}$ & 0.00936 & $0.02129^{a}$ & $0.02386^{a}$ \\
\hline & [0.013811] & [0.013543] & [0.0079] & [0.008176] \\
\hline$R^{2}$ & 0.61203 & 0.49479 & 0.36535 & 0.36659 \\
\hline Adj. $R^{2}$ & 0.35785 & 0.25481 & 0.22987 & 0.23137 \\
\hline SSR & 0.01327 & 0.00796 & 0.03173 & 0.03167 \\
\hline F-statistic & $2.40782^{b}$ & $2.06184^{b}$ & $2.69661^{a}$ & $2.71102^{a}$ \\
\hline
\end{tabular}

Note: $\left({ }^{\mathrm{a}}\right),\left(^{\mathrm{b}}\right)$ and $\left({ }^{(}\right)$have been used to indicate that the coefficient estimations are statistically significant at $1 \%, 5 \%$ and $10 \%$ level, respectively. $\left({ }^{\text {d }}\right)$ The values given in brackets under related coefficient estimations are Newey-West robust standard errors. ( ${ }^{\mathrm{e}}$ ) In order to save space, only the 
statistically significant variables are included here. (f) To narrow the research to a smaller area, only the test results related to the specification 1 shown in Table 3 are reported here. Specification 1 is the most general model.

All Coefficients of $\beta_{1}$ in Table 7 are estimated to be negative and statistically significant at $1 \%$ level. Regression coefficients of $\beta_{1}$ suggest that workers with negative mood due to TV series finales cause a decrease in the Turkish industrial production. The findings in Table 7 are consistent with previous results of this paper and establish the robustness of the negative mood effect on Turkish industrial production performance.

\section{Conclusion and Remarks}

The parasocial breakups and consequent mood swings in human beings are evident from psychological studies on TV series, movies and theatre plays. However, its effect on industrial performance is not analysed and not fully understood yet. We use parasocial breakup as a proxy for the negative mood of workers in Turkey and analyse how workers' negative mood affects Turkish industrial production performance. This study presents robust evidence that long-running TV series finales influence the industrial performance in the context of parasocial breakup concept.

The outcomes of this paper summarized as follows: (i) negative mood (i.e. parasocial breakup) has been found to decrease Turkish industrial production in accordance with the findings in the literature; (ii) this decreasing effect of parasocial breakup becomes different according to the types of the TV series and the channels they are broadcasted on; (iii) the rate of cloudiness as another negative mood proxy also affect the industrial production negatively. In conclusion, negative alterations in workers' mood due to TV series finales have a negative emphatic effect on industrial production in Turkey because of the workers' performance-decreasing effect of negative mood.

To the best of our knowledge, this is the first paper to examine the effect of parasocial breakup on industrial production performance. The findings of this paper may have some theoretical implication for future researches. For example, it would be interesting to investigate the effect of long-running TV series finales on industrial production performance for other countries. The impact of workers' mood on productivity is a rich area.

As a result of this paper, industrial production performances respond negatively to the drama TV series finales and the finales broadcasted on Show TV and Star TV channels in particular. As might be predicted, the importance of each long-running TV series is not the same. These results have several important implications for media bosses and producers of TV series in Turkey. Media bosses in Turkey can prefer to serialise more drama TV series to increase the ratings of their channels by strengthening the power of parasocial relationship. Producers of TV series, on the other hand, prefer to represent their TV series to Show TV and Star TV in order to be on the air their TV shows for a longer time by increasing the recognition potential of TV personae.

\section{References}

Akbari, J., Dehghan, H., Azmoon, H., \& Forouharmajd, F. (2013). Relationship between lighting and noise levels and productivity of the occupants in automotive assembly industry. Journal of environmental and public health, 2013.

Al Mamun, K. A., \& Nath, H. K. (2005). Export-led growth in Bangladesh: a time series analysis. Applied Economics Letters, 12(6), 361-364.

Amabile, T. M., Barsade, S. G., Mueller, J. S., \& Staw, B. M. (2005). Affect and creativity at work. Administrative science quarterly, 50(3), 367-403. 
INTERNATIONAL JOURNAL OF ACADEMIC RESEARCH IN BUSINESS AND SOCIAL SCIENCES Vol. 8, No. 9, Sept. 2018, E-ISSN: 2222-6990 @ 2018 HRMARS

Ashkanasy, N. M., \& Humphrey, R. H. (2011). Current emotion research in organizational behavior. Emotion Review, 3(2), 214-224.

Barişik, S., \& Yayar, R. (2012). Sanayi üretim endeksini etkileyen faktörlerin ekonometrik analizi. Iktisat Isletme ve Finans, 27(316), 53-70.

Baranski, J. V., Cian, C., Esquievie, D., Esquivié,, R. A., \& Raphel, C. (1998). Modafinil during 64 hr of sleep deprivation: Dose-related effects on fatigue, alertness, and cognitive performance. Military Psychology, 10(3), 173-193.

Badayai, A. R. A. (2012). A theoretical framework and analytical discussion on uncongenial physical workplace environment and job performance among workers in industrial sectors. ProcediaSocial and Behavioral Sciences, 42, 486-495.

Baumeister, R. F., Campbell, J. D., Krueger, J. I., \& Vohs, K. D. (2003). Does high self-esteem cause better performance, interpersonal success, happiness, or healthier lifestyles?. Psychological science in the public interest, 4(1), 1-44.

Berument, H., \& Yucel, E. M. (2005). Long live Fenerbahçe: The production boosting effects of football. Journal of Economic Psychology, 26(6), 842-861.

Binnewies, C., \& Wörnlein, S. C. (2011). What makes a creative day? A diary study on the interplay between affect, job stressors, and job control. Journal of Organizational Behavior, 32(4), 589607.

Blagrove, M., \& Akehurst, L. (2001). Personality and the modulation of effects of sleep loss on mood and cognition. Personality and Individual Differences,30(5), 819-828.

Bono, J. E., \& Ilies, R. (2006). Charisma, positive emotions and mood contagion. The Leadership Quarterly, 17(4), 317-334.

Carnevale, P. J., \& Isen, A. M. (1986). The influence of positive affect and visual access on the discovery of integrative solutions in bilateral negotiation. Organizational behavior and human decision Processes, 37(1), 1-13.

Chen, Y., Hsu, P. H., Podolski, E. J., \& Veeraraghavan, M. (2016). In the Mood for Creativity: WeatherInduced Mood, Inventor Productivity, and Firm Value. http://econfin.massey.ac.nz/school/documents/seminarseries/manawatu/In\%20the\%20moo d\%20for\%20creativity\%20-\%2010-10-2017.pdf

Cohen, J. (2003). Parasocial Break-ups: Measuring Individual Differences in Responses to the Dissolution of Parasocial Relationships. Mass Communication \& Society, 6 (2), 191-202.

Cohen, J. (2004). Parasocial Break-up from Favorite Television Characters: The Role of Attachment Styles and Relationship Intensity. Journal of Social and Personal Relationships, 21, 187-202.

Connolly, J. J., \& Viswesvaran, C. (2000). The role of affectivity in job satisfaction: A metaanalysis. Personality and individual differences, 29(2), 265-281.

Corradi, V., Distaso, W., \& Mele, A. (2013). Macroeconomic determinants of stock volatility and volatility premiums. Journal of Monetary Economics, 60(2), 203-220.

Côté, S. (1999). Affect and performance in organizational settings. Current Directions in Psychological Science, 8(2), 65-68.

Cropanzano, R., \& Wright, T. A. (1999). A 5-year study of change in the relationship between wellbeing and job performance. Consulting Psychology Journal: Practice and Research, 51(4), 252.

Credé, M., Chernyshenko, O. S., Stark, S., Dalal, R. S., \& Bashshur, M. (2005). The relationship of job satisfaction to personological and environmental antecedents and volitional workplace behavior. Manuscript submitted for publication. 
INTERNATIONAL JOURNAL OF ACADEMIC RESEARCH IN BUSINESS AND SOCIAL SCIENCES

Vol. 8, No. 9, Sept. 2018, E-ISSN: 2222-6990 @ 2018 HRMARS

Eisenberger, R., Armeli, S., Rexwinkel, B., Lynch, P. D., \& Rhoades, L. (2001). Reciprocation of perceived organizational support. Journal of applied psychology, 86(1), 42-51.

Espinoza, R., Fornari, F., \& Lombardi, M. J. (2012). The role of financial variables in predicting economic activity. Journal of Forecasting, 31(1), 15-46.

Estrada, C. A., Isen, A. M., \& Young, M. J. (1994). Positive affect improves creative problem solving and influences reported source of practice satisfaction in physicians. Motivation and emotion, 18(4), 285-299.

Eyal, K., \& Cohen, J. (2006). When Good Friends Say Goodbye: A Parasocial Breakup Study. Journal of Broadcasting \& Electronic Media, 50 (3), 502 - 523.

Faust, J., Gilchrist, S., Wright, J. H., \& Zakrajšsek, E. (2013). Credit spreads as predictors of real-time economic activity: a Bayesian model-averaging approach. Review of Economics and Statistics, 95(5), 1501-1519.

Field, T., Diego, M., Pelaez, M., Deeds, O., \& Delgado, J. (2009). Breakup distress in university students. Adolescence, 44(176), 705-727.

Fisher, C. D. (2002). Antecedents and consequences of real-time affective reactions at work. Motivation and Emotion, 26, 3-30.

Forgas, J. P. (2000). Feeling and thinking: The role of affect in social cognition. New York: Cambridge University Press.

Fornari, F., \& Mele, A. (2013). Financial volatility and economic activity.Journal of Financial Management, Markets and Institutions, 1(2), 155-198.

Fuller, J. A., Stanton, J. M., Fisher, G. G., Spitzmüller, C., Russell, S. S., \& Smith, P.C. (2003). A lengthy look at the daily grind: Time series analysis of events, mood, stress, and satisfaction. Journal of Applied Psychology, 88, 1019-1033.

George, J. M. (1989). Mood and absence. Journal of Applied Psychology, 74, 317-324.

George, J. M. (1991). State or trait: Effects of positive mood on prosocial behaviors at work. Journal of Applied Psychology, 76, 299-307.

George, J. M., \& Brief, A. P. (1996). Motivational agendas in the workplace: The effects of feelings on focus of attention and work motivation. Research in Organizational Behavior, 18, 75-109.

George, J. M., \& Zhou, J. (2002). Understanding when bad moods foster creativity and good ones don't: the role of context and clarity of feelings.Journal of Applied Psychology, 87(4), 687.

Gil, K. M., Carson, J. W., Porter, L. S., Scipio, C., Bediako, S. M., \& Orringer, E. (2004). Daily mood and stress predict pain, health care use, and work activity in African American adults with Sicklecell disease. Health Psychology, 23, 267-274.

Herrbach, O. (2006). A matter of feeling? The affective tone of organizational commitment and identification. Journal of Organizational Behavior, 27(5), 629-643.

http://www.ntv.com.tr/ekonomi/turkiye-dizi-ihracatinda-dunyadaikinci,gWxDP1YE5E2bbsqU6cQxSw

Ilies, R., Dimotakis, N., \& Watson, D. (2010). Mood, blood pressure, and heart rate at work: an experience-sampling study. Journal of occupational health psychology, 15(2), 120.

Iverson, R. D., Olekalns, M., \& Erwin, P. J. (1998). Affectivity, organizational stressors, and absenteeism: A causal model of burnout and its consequences. Journal of Vocational Behavior, 52, 1-23.

Judge, T. A., Thoresen, C. J., Pucik, V., \& Welbourne, T. M. (1999). Managerial coping with organizational change: A dispositional perspective. Journal of applied psychology, 84(1), 107. 
INTERNATIONAL JOURNAL OF ACADEMIC RESEARCH IN BUSINESS AND SOCIAL SCIENCES Vol. 8, No. 9, Sept. 2018, E-ISSN: 2222-6990 @ 2018 HRMARS

Judge, T. A., \& llies, R. (2004). Affect and job satisfaction: A study of their relationship at work and at home. Journal of Applied Psychology, 4, 661-673.

Junttila, J. (2007). Forecasting the macroeconomy with contemporaneous financial market information: Europe and the United States. Review of Financial Economics, 16(2), 149-175.

Kessler, R. C., Berglund, P. A., Coulouvrat, C., Hajak, G., Roth, T., Shahly, V., Shillington, AC., Stephenson, JJ., Walsh, JK. (2011). Insomnia and the perfor-mance of Us workers: results from the America Insomnia survey. Sleep, 34(9), 1161-1171.

Kwallek, N., Lewis, C. M., \& Robbins, A. S. (1988). Effects of office interior color on workers' mood and productivity. Perceptual and Motor Skills, 66(1), 123-128.

Lee, J. J., Gino, F., \& Staats, B. R. (2014). Rainmakers: Why bad weather means good productivity. Journal of Applied Psychology, 99(3), 504.

Lee, K., \& Ni, S. (2002). On the dynamic effects of oil price shocks: a study using industry level data. Journal of Monetary Economics, 49(4), 823-852.

Lepori, G.M. (2015). Investor mood and demand for stocks: Evidence from popular TV series finales. Journal of Econonomic Psychology, 48(2015), 33-47.

Lesiuk, T. (2005). The effect of music listening on work performance. Psychology of music, 33(2), 173191.

Lohr, V. I., Pearson-Mims, C. H., \& Goodwin, G. K. (1996). Interior plants may improve worker productivity and reduce stress in a windowless environment. Journal of Environmental Horticulture, 14, 97-100.

Lyubomirsky, S., King, L., \& Diener, E. (2005). The benefits of frequent positive affect: does happiness lead to success?. Psychological bulletin, 131(6), 803.

Madjar, N., Oldham, G. R., \& Pratt, M. G. (2002). There's no place like home? The contributions of work and nonwork creativity support to employees' creative performance. Academy of Management Journal, 45(4), 757-767.

Magnini, V. P., \& Parker, E. E. (2009). The psychological effects of music: Implications for hotel firms. Journal of Vacation Marketing, 15(1), 53-62.

McCarthy, C. J., Lambert, R. G., \& Brack, G. (1997). Structural model of coping, appraisals, and emotions after relationship breakup. Journal of Counseling \& Development, 76(1), 53-64.

Mignonac, K., \& Herrbach, O. (2004). Linking work events, affective states, and attitudes: An empirical study of managers' emotions. Journal of Business and Psychology, 19(2), 221-240.

Miles, D. E., Borman, W. E., Spector, P. E., \& Fox, S. (2002). Building an integrative model of extra role work behaviors: A comparison of counterproductive work behavior with organizational citizenship behavior. International Journal of Selection and Assessment, 10, 51-57.

Miner, A. G., Glomb, T. M., \& Hulin, C. (2005). Experience sampling mood and its correlates at work. Journal of Occupational and Organizational Psychology, 78, 171-193.

Miner, A. G., \& Glomb, T. M. (2010). State mood, task performance, and behavior at work: A withinpersons approach. Organizational Behavior and Human Decision Processes, 112(1), 43-57.

Moody, J., Levin, U., \& Rehfuss, S. (1993). Predicting the U.S. index of industrial production (extended abstract) . CSETech. Paper 310. http://digitalcommons.ohsu.edu/csetech/310

Okoye, P. V. C., \& Ezejiofor, R. A. (2013). The effect of human resources development on organizational productivity. International Journal of Academic Research in Business and Social Sciences, 3(10), 250. 
INTERNATIONAL JOURNAL OF ACADEMIC RESEARCH IN BUSINESS AND SOCIAL SCIENCES

Vol. 8, No. 9, Sept. 2018, E-ISSN: 2222-6990 @ 2018 HRMARS

Padmasiri, M. K. D., \& Dhammika, K. A. S. (2014). The Effect Of Music Listening On Work Performance: A Case Study Of Sri Lanka. International Journal of Technology Enhancements and Emerging Engineering Research,3(5), 118-122.

Pilcher, J. J., \& Huffcutt, A. J. (1996). Effects of sleep deprivation on performance: a metaanalysis. Sleep, 19(4), 318-326.

Rhoades, G. K., Kamp-Dush, C. M., Atkins, D. C., Stanley, S. M., \& Markman, H. J. (2011). Breaking up is hard to do: The impact of unmarried relationship dissolution on mental health and life satisfaction. Journal of Family Psychology, 25(3), 366-374.

RTÜK (2013). Televizyon İzleme Ağaştırması 2012.http://www.rtuk.org.tr/Icerik/DownloadReport/13

Rubin, R.B., \& McHugh, M.P. (1987). Development of Parasocial Relationships. Journal ofBroadcasting \& Electronic Media, 31(3), 279 - 292.

Schwarz, N., \& Clore, G. L. (1983). Mood, misattribution, and judgments of well-being: Informative and directive functions of affective states. Journal of personality and social psychology, 45(3), 513-523.

Seo, M. G., Bartunek, J. M., \& Barrett, L. F. (2010). The role of affective experience in work motivation: Test of a conceptual model. Journal of Organizational Behavior, 31(7), 951-968.

Slotter, E. B., Gaedner, W. L., \& Finkel, E. J. (2010). Who am I without you? The influence of romantic breakup on the self-concept. Personality and Social Psychology Bulletin, 36(2), 147-160.

Staw, B. M., Sutton, R. I., \& Pelled, L. H. (1994). Employee positive emotion and favorable outcomes at the workplace. Organization Science, 5(1), 51-71.

Tennant, C. (2001). Work-related stress and depressive disorders. Journal of psychosomatic research, 51(5), 697-704.

Totterdell, P., Briner, R. B., Parkinson, B., \& Reynolds, S. (1996). Fingerprinting time series: Dynamic patterns in self-report and performance measures uncovered by a graphical non-linear method. British Journal of Psychology, 87(1), 43-60.

Thoresen, C. J., Kaplan, S. A., Barsky, A. P., Warren, C. R., \& de Chermont, K. (2003). The affective underpinnings or job perceptions and attitudes: A meta-analytic review and integration. Psychological Bulletin, 129, 914-945.

Totterdell, P. (1999). Mood scores: Mood and performance in professional cricketers. British Journal of Psychology, 90, 317.

Tsai, W. C., Chen, C. C., \& Liu, H. L. (2007). Test of a model linking employee positive moods and task performance. Journal of Applied Psychology, 92(6), 1570.

Van Bommel, W.J.M., Van den Beld, G.J., Van Ooijen, M.H.F., (2002). Industrial Lighting and Productivity. The Netherlands: Philips Lighting. http://elementsenergytechnology.com/assets/industrial-lighting-and-productivity.pdf

Vosburg, S. K. (1998). Mood and the quantity and quality of ideas. Creativity Research Journal, 11(4), 315-324.

Weiss, H. M., Nicholas, J. P., \& Daus, C. S. (1999). An examination of the joint effects of affective experiences and job beliefs on job satisfaction and variations in affective experiences over time. Organizational behavior and human decision processes, 78(1), 1-24. 